\title{
PENGARUH PEMBERIAN IMUNOMODULATOR JINTAN HITAM (Nigella sativa) TERHADAP TITER ANTIBODI AVIAN INFLUENZA dan NEWCASTLE DISEASE PADA BROILER JANTAN
}

\author{
The Effect of Giving Black Cumin (Nigella sativa) as Immunomodulator on Antibody Titer of Avian \\ Influenza and Newcastle Disease in Male Broiler
}

\author{
Dwi Prasetyo, Purnama Edy Santosa, Madi Hartono, dan Muhammad Mirandy Pratama Sirat
}

Departemen of Animal Husbandry, Faculty of Agriculture, University of Lampung

Jl Prof Dr Soemantri Brojonegoro No. 1 Gedung Meneng Bandar Lampung 35145

e-mail: dwiprasetyoa7x@,Fp.unila.ac.id

\begin{abstract}
This study aimed to determine the effect of giving black cumin (Nigella sativa) as an immunomodulator on Avian Influenza (AI) and Newcastle Disease (ND) antibody titers in male broilers. This study was conducted in December 2019--January 2020 at the Laboratory of Integrated Field, Faculty of Agriculture, University of Lampung. Analysis of antibody titers was carried out at the Laboratory of Virology, Veterinary Disease Investigation Center Region Lampung. This study used a Completely Randomized Design with four treatments and three replications namely drinking water without Nigella sativa (P0), drinking water with $36 \mathrm{mg} / \mathrm{kg}$ BW/day Nigella sativa (P1), drinking water with $72 \mathrm{mg} / \mathrm{kg}$ BW/day Nigella sativa (P2), and drinking water with $144 \mathrm{mg} / \mathrm{kg}$ BW/day Nigella sativa (P3). The results of this study showed that administration of Nigella sativa had no significant effect on antibody titer of AI, but had significant effect on antibody titer of ND and administration $72 \mathrm{mg} / \mathrm{kg}$ BW/day of Nigella sativa was the best in increasing the antibody titer of ND in male broilers.
\end{abstract}

Keywords: Avian Influenza, Black cumin, Male broiler, Newcastle Disease, Titer antibody

\begin{abstract}
ABSTRAK
Penelitian ini bertujuan untuk mengetahui pengaruh pemberian jintan hitam (Nigella sativa) sebagai imunomodulator terhadap titer antibodi Avian Influenza (AI) dan Newcastle Disease (ND) pada broiler jantan dan dilaksanakan pada Desember 2019--Januari 2019 di Laboratorium Lapang Terpadu, Fakultas Pertanian, Universitas Lampung. Analisis titer antibodi dilakukan di Laboratorium Virologi Balai Veteriner Lampung. Penelitian ini menggunakan Rancangan Acak Lengkap (RAL) dengan empat perlakuan dan tiga ulangan yaitu air minum tanpa Nigella sativa (P0), dan air minum dengan $36 \mathrm{mg} / \mathrm{kg}$ $\mathrm{BB} /$ hari Nigella sativa (P1), air minum dengan $72 \mathrm{mg} / \mathrm{kg} \mathrm{BB} /$ hari Nigella sativa (P2), air minum dengan $144 \mathrm{mg} / \mathrm{kg} \mathrm{BB} /$ hari Nigella sativa (P3). Berdasarkan analisis ragam, hasil penelitian ini menunjukkan bahwa pemberian Nigella sativa tidak berpengaruh nyata $(\mathrm{P}>0,05)$ terhadap titer antibodi AI pada broiler jantan, namun berpengaruh nyata $(\mathrm{P} \leq 0,05)$ terhadap titer antibodi ND pada pemberian Nigella sativa dengan dosis $72 \mathrm{mg} / \mathrm{kg} \mathrm{BB} /$ hari dapat meningkatkan titer antibodi Newcastle Disease secara nyata pada broiler jantan.
\end{abstract}

Kata Kunci : Avian Influenza, Broiler jantan, Jintan hitam, Newcastle Disease, Titer Antibodi

\section{PENDAHULUAN}

Pendapatan bruto perkapita penduduk Indonesia selama 4 tahun terakhir mengalami peningkatan. Pada tahun 2015 pendapatan bruto per kapita sebesar Rp. 45.000.000,12 sedangkan pada tahun 2019 pendapatan bruto per kapita sebesar Rp.59.000.000,1 (BPS, 2020) mengalami peningkatan sebesar $31,1 \%$ hal ini berpengaruh pada konsumsi protein hewani di
Indonesia. Ayam pedaging (broiler) merupakan salah satu komoditi unggas yang memberikan kontribusi besar dalam memenuhi kebutuhan protein asal hewani bagi masyarakat Indonesia. Kebutuhan daging ayam setiap tahunnya mengalami peningkatan, dibuktikan berdasarkan data Kementrian Perdagangan (2020) yang menyatakan bahwa konsumsi daging ayam broiler di Indonesia tahun 2015 sebesar 2.038.869 ton, atau mengalami peningkatan 
sebesar 7,51 \% dari konsumsi tahun 2019 sebesar 2.194.029 ton, hal ini membuktikan bahwa broiler merupakan komoditas yang banyak diminati oleh berbagai kalangan masyarakat.

Keunggulan broiler didukung oleh sifat genetik dan keadaan lingkungan meliputi makanan, temperatur lingkungan, dan pemeliharaan, namun broiler memiliki kelemahan yaitu rentan terhadap serangan penyakit, terutama penyakit yang disebabkan oleh virus seperti Avian Influenza (AI) dan Newcastle Disease (ND). Penyakit ini adalah dua penyakit pada unggas yang dapat menyebabkan wabah berulang dan seringkali menimbulkan gejala klinis dan lesi patologis yang serupa pada unggas dengan morbiditas dan mortalitas tinggi sehingga menyebabkan kerugian ekonomis yang besar pada industri perunggasan (Ekaningtias et al., 2017).

Kasus penyakit yang disebabkan oleh virus dapat dicegah dengan cara meningkatkan titer antibodi pada broiler. Antibodi merupakan protein- protein yang terbentuk sebagai respon terhadap antigen yang masuk ke tubuh. Peningkatan respon terhadap antigen dialakukan dengan peningkatan titer antibodi. Titer antibodi merupakan ukuran jumlah unit antibodi per unit volume serum (Subowo, 2009). Titer antibodi dapat ditingkatkan dengan cara memberikan bahan tambahan sebagai perangsang sistem imun atau dikenal sebagai imunomodulator. Nigella sativa termasuk obat herbal sebagai imunomodulator dengan khasiat sebagai antioksidan, anti inflamasi, anti mikroba, anti neoplasma dan dapat meningkatkan sekresi insulin (Salama, 2010).

Penggunaan Jintan hitam dalam penelitian yang dilakukan oleh Rohyati (2002) menghasilkan bahwa adanya senyawa ekstrak etanol pada jintan hitam yang dapat meningkatkan kekebalan tubuh yaitu melalui peningkatan pembentukan sel leukosit, sel sumsum tulang dan peningkatan bobot limfa dimana organ tersebut berpengaruh pada produksi imun tubuh broiler.

Pemilihan broiler jantan dalam penelitian ini dilakukan karena adanya perbedaan antara broiler jantan dan betina pada organ limfoid sebagai organ pembentuk antibodi. Pada ayam jantan perkembangan bursa Fabricius yang merupakan tempat produksi antibodi mengalami penghambatan oleh hormon testosteron, sedangkan hormon estrogen pada ayam betina tidak menghambat perkembangan bursa Fabricius (Rohyati, 2002). Pemberian Nigella sativa yang dilarutkan dalam air minum diharapkan dapat meningkatkan sistem imun dan dapat meningkatkan titer antibodi broiler jantan. Penelitian tentang pengaruh pemberian Nigella sativa pada broiler terhadap titer antibodi AI dan ND khususnya di Indonesia sampai saat ini belum ada, maka, penelitian ini dilakukan untuk mengetahui titer antibodi broiler jantan yang dihasilkan dari pemberian Nigella sativa sebagai imunomodulator.

\section{MATERI DAN METODE}

Penelitian ini dilaksanakan pada Desember 2019-Januari 2020 di unit kandang Laboratorium Lapang Terpadu, Fakultas Pertanian, Universitas Lampung. Sampel darah penelitian ini dianalisis di Balai Veteriner Lampung, Bandar Lampung, Provinsi Lampung.

\section{Materi}

Materi penelitian adalah Day Old Chiken (DOC) broiler jantan strain Cobb CP 707, ransum N-511, air minum, ekstrak Nigella sativa (jintan hitam), vaksin Newcastle Disease (ND), vaksin Newcastle Disease dan Avian Influenza (NDAI), vaksin Infectious Bursal Disease (IBD), darah broiler, alkohol 70\%; isotonis PBS pH 7,0-7,4, cairan chorion allantois, antisera ND dan AI, serta RBC 1\%. Kandang broiler, plastik terpal, koran,sekam, lampu bohlam, hanging feeder, chick feeder tray, tempat minum, ember, hand spray, timbangan elektrik, thermohygrometer, kapas, disposable syringe, cooler box, micromixer, microplate bentuk V, dan micropipemultichannel, alat tulis dan kertas.

\section{Metode}

Penelitian ini dilakukan menggunakan Rancangan Acak Lengkap (RAL) dengan empat perlakuan dan tiga ulangan. Perlakuan yang diberikan yaitu air minum tanpa Nigella sativa (P0), air minum dengan $36 \mathrm{mg} / \mathrm{kg} \mathrm{BB} /$ hari Nigella sativa (P1), air minum dengan $72 \mathrm{mg} / \mathrm{kg}$ $\mathrm{BB} /$ hari Nigella sativa (P2), air minum dengan $144 \mathrm{mg} / \mathrm{kg} \mathrm{BB} /$ hari Nigella sativa (P3).

Setiap pukul 06.00 WIB dilakukan penimbangan sampel broiler untuk mendapatkan data bobot badan yang dijadikan dasar untuk menghitung dosis Nigella sativa sesuai perlakuan, kemudian broiler dipuasakan selama satu jam. Pukul 07.00 WIB broiler diberi air minum dengan perlakuan dilanjutkan pemberian air minum secara ad libitum.

Pengukuran suhu dan kelembaban kandang dilakukan setiap hari, yaitu pada pukul 07.00, 12.00, dan 17.00 WIB. Pakan diberikan secara ad libitum. Program vaksinasi broiler dilakukan untuk mencegah penyakit yang dapat menurunkan produktivitas. Vaksinasi yang 
dilakukan yaitu vaksinasi ND live, NDAI killed, dan IBD. Broiler umur 6 hari diberikan vaksin NDAI killed melalui injeksi pada bagian subkutan leher dan $N D$ live melalui tetes mata. Umur 12 hari dilakukan vaksinasi IBD melalui air minum.

Pengambilan sampel darah dilakukan ketika broiler berumur 31 hari. Sampel darah diambil menggunakan disposable syringe $5 \mathrm{ml}$ melalui vena brachialis, Sampel darah yang telah diambil didiamkan tetap berada di dalam dispossable syringe dan didiamkan sampai terjadi pemisahan antara darah dengan serum darah yang berwarna kuning. Serum darah kemudian dimasukkan ke dalam tabung eppendorf dan diberi label sesuai dengan perlakuan. Serum dikirim ke Laboratorium Virologi Balai Veteriner Lampung untuk analisis titer antibodi ND dan AI.

\section{HASIL DAN PEMBAHASAN}

\section{Pengaruh perlakuan terhadap Titer Antibodi Avian Influenza (AI) pada Broiler Jantan}

Hasil pemeriksaan titer antibodi Avian Influenza (AI) pada masing-masing perlakuan disajikan pada Tabel 1. Pemeriksaan titer antibodi dilakukan untuk mengetahui kemampuan protein serum yang mengandung antibodi untuk mengumpulkan dan menghancurkan antigen yang masuk ke dalam tubuh (Subowo, 2009). Hasil analisis ragam menunjukan bahwa tidak terdapat perbedaan yang nyata pada setiap perlakuan, namun hasil uji Hemagglutination Inhibition (HI) yang dihasilkan menunjukan bahwa broiler dengan pemberian Nigella sativa dengan dosis 144 $\mathrm{mg} / \mathrm{kg} \mathrm{BB} /$ hari (P3) dengan rataan titer antibodi sebesar 17,33 menunjukan protektif terhadap penyakit AI hal ini sesuai dengan pendapat Alfons (2005) yang menyatakan titer antibodi protektif AI adalah $>\log 2^{4}$ atau $>16$ melalui uji HI.

Hasil analisis titer antibodi AI yang rendah pada perlakuan tersebut kemungkinan dapat disebabkan oleh beberapa faktor seperti penggunaan vaksin inaktif/killed vaccine yang menyebabkan titer antibodi AI belum terbentuk. Pemberian vaksin inaktif umumnya menghasilkan respons imun yang lambat. Respons imun yang terbentuk pada vaksin inaktif lebih lambat jika dibandingkan dengan menggunakan vaksin aktif. Hal ini disebabkan karena vaksin inaktif mengandung oil adjuvant yang berfungsi sebagai depo antigen sehingga antigen vaksin akan dilepaskan secara perlahanlahan (Aiyer et al., 2013).
Vaksinasi AI killed/inaktif dilakukan pada umur ke-6, rendahnya titer antibodi juga diduga dipengaruhi oleh maternal antibodi broiler yang menetralisir vaksin. Menurut Hamal et al. (2006) nilai titer antibodi maternal akan berangsur turun pada hari ke-7 dan akan hilang pada hari ke-14 dan ditambahkan Prabowo (2003), keberadaan antibodi maternal yang masih tinggi dalam tubuh ayam akan dapat menetralisasi antigen vaksin yang berakibat pada berkurangnya respon vaksin yang diberikan sehingga menyebabkan kegagalan vaksinasi.

\section{Pengaruh perlakuan terhadap Titer Antibodi Newcatle Disease (ND) pada Broiler Jantan}

Hasil pemeriksaan titer antibodi Newcastle Disease (ND) masing-masing perlakuan disajikan pada Tabel 2. Hasil analisis ragam menunjukkan bahwa perlakuan pemberian jintan hitam (Nigella sativa) berpengaruh secara nyata $(\mathrm{P} \leq 0,05)$ terhadap titer antibodi ND pada broiler jantan. Hasil dalam penelitian ini menunjukkan bahwa Nigella sativa yang digunakan dalam penelitian ini efektif untuk meningkatkan titer antibodi ND pada broiler jantan. Menurut Allan et al., (1978) bahwa titer antibodi ND dikatakan protektif apabila memiliki nilai uji $\mathrm{HI}>\log 2^{5}$ atau $>32$. Pada penelitian ini perlakuan yang memberikan hasil protektif terhadap ND adalah pada perlakuan dengan pemberian Nigella sativa $72 \mathrm{mg} / \mathrm{kg}$ $\mathrm{BB} /$ hari (P2) dan $144 \mathrm{mg} / \mathrm{kg}$ BB/hari (P3) dengan masing-masing rata-rata titer antibodi ND 64 (P2) dan 42,67 (P3).

Berdasarkan uji lanjut Beda Nyata Terkecil (BNT) didapatkan hasil bahwa perlakuan tanpa pemberian Nigella sativa (P0) berbeda nyata $(\mathrm{P} \leq 0,05)$ jika dibandingkan dengan pemberian Nigella sativa pada air minum dengan dosis $36 \mathrm{mg} / \mathrm{kg} \mathrm{BB} /$ hari $(\mathrm{P} 1)$, namun tidak berbeda nyata $(\mathrm{P}>0,05)$ jika dibandingkan dengan pemberiaNigella sativa pada air minum dengan dosis $144 \mathrm{mg} / \mathrm{kg} \mathrm{BB} /$ hari (P3), antara perlakuan pemberian Nigella sativa pada air minum dengan dosis $36 \mathrm{mg} / \mathrm{kg} \mathrm{BB} /$ hari (P1) dan $144 \mathrm{mg} / \mathrm{kg} \mathrm{BB} /$ hari (P3) tidak berbeda nyata $(\mathrm{P}>0,05)$ terhadap titer antibodi Newcastle disease, sedangkan pada perlakuan pemberian Nigella sativa pada air minum dengan dosis 72 $\mathrm{mg} / \mathrm{kg}$ BB/hari (P2) sangat berbeda nyata $(\mathrm{P} \leq 0,01)$ jika dibandingkan dengan pemberian Nigella sativa pada air minum dengan dosis 36 $\mathrm{mg} / \mathrm{kg} \mathrm{BB} /$ hari (P1), namun tidak berbeda nyata jika dibandingkan dengan perlakuan tanpa pemberian Nigella sativa (P0) dan $144 \mathrm{mg} / \mathrm{kg}$ $\mathrm{BB} /$ hari (P3). 
Tabel 1. Hasil uji HI titer antibodi Avian Influenza

\begin{tabular}{|c|c|c|c|c|}
\hline \multirow{2}{*}{ Ulangan } & \multicolumn{4}{|c|}{ Perlakuan } \\
\hline & P0 & $\mathrm{P} 1$ & $\mathrm{P} 2$ & P3 \\
\hline & & ------- & ------ & \\
\hline 1 & 0 & 8 & 0 & 16 \\
\hline 2 & 4 & 0 & 4 & 32 \\
\hline 3 & 16 & 8 & 8 & 4 \\
\hline Jumlah & 20 & 16 & 12 & 52 \\
\hline Rata-rata & 6,67 & 5,33 & 4,00 & 17,33 \\
\hline
\end{tabular}

Keterangan :

P0 : air minum tanpa jintan hitam (Nigella sativa);

$\mathrm{P} 1$ : air minum dengan dosis $36 \mathrm{mg} / \mathrm{kg} \mathrm{BB} /$ hari jintan hitam (Nigella sativa);

$\mathrm{P} 2$ : air minum dengan dosis $72 \mathrm{mg} / \mathrm{kg} \mathrm{BB} /$ hari jintan hitam (Nigella sativa);

P3 : air minum dengan dosis $144 \mathrm{mg} / \mathrm{kg} \mathrm{BB} /$ hari jintan hitam (Nigella sativa).

Tabel 2. Hasil uji HI titer antibodi Newcastle Disease

\begin{tabular}{|c|c|c|c|c|}
\hline \multirow{2}{*}{ Ulangan } & \multicolumn{4}{|c|}{ Perlakuan } \\
\hline & $\mathrm{P} 0$ & $\mathrm{P} 1$ & $\mathrm{P} 2$ & P3 \\
\hline 1 & 32 & 16 & 64 & 64 \\
\hline 2 & 64 & 4 & 64 & 32 \\
\hline 3 & 64 & 32 & 64 & 32 \\
\hline Jumlah & 160 & 52 & 192 & 128 \\
\hline Rata-rata & $53,33^{b}$ & $17,33^{\mathrm{a}}$ & $64,00^{\mathrm{b}}$ & $42,67^{\mathrm{ab}}$ \\
\hline
\end{tabular}

Keterangan :

P0 : air minum tanpa jintan hitam (Nigella sativa);

$\mathrm{P} 1$ : air minum dengan dosis $36 \mathrm{mg} / \mathrm{kg} \mathrm{BB} /$ hari jintan hitam (Nigella sativa);

P2 : air minum dengan dosis $72 \mathrm{mg} / \mathrm{kg} \mathrm{BB} /$ hari jintan hitam (Nigella sativa);

P3 : air minum dengan dosis $144 \mathrm{mg} / \mathrm{kg} \mathrm{BB} /$ hari jintan hitam (Nigella sativa).

Berdasarkan uji lanjut Beda Nyata Terkecil (BNT) didapatkan hasil bahwa perlakuan P1, jika dibandingkan dengan P0 dan P2 berbeda nyata, namun tidak berbedanyata jika dibandingkan dengan P3. Pada perlakuan P1 $(17,33)$ titer antibodi yang dihasilkan belum protektif bahkan lebih rendah dari P0 $(53,33)$, diduga hal ini terjadi karena kandungan minyak atsiri pada dosis tertentu menurunkan titer antibodi sehingga titer antibodi yang terbentuk belum protektif atau Nigella sativa yang diberikan bertindak sebagai imonosupresi yang menekan aktifitas sistem imun pada broiler jantan. Menurut Islam et al. (2004) yang melakukan penelitian imunosupresi dari minyak atsiri Nigella sativa pada tikus yang telah di imunisasi dengan Salmonella thypi-H dengan melihat parameter titer antibodi dan parameter sel imun perifer. Hasilnya menunjukkan bahwa minyak atsiri menurunkan titer antibodi serum. Baratawidjaja (2009) menambahkan imunosupresi menekan aktivitas sistem imun dengan cara penghambatan transkip dari sitokin, sehingga rantai penting dalam sistem imun diperlemah khususnya IL-2. IL-2 esensial bagi perbanyakan dan deferensial limfosit, yang dapat dihambat oleh efek sitostatis langsung.

Berdasarkan uji lanjut Beda Nyata Terkecil (BNT) (Tabel 2) didapatkan hasil bahwa perlakuan P2, jika dibandingkan dengan P1 berbedanyata, namun tidak berbedanyata jika dibandingkan dengan P0 dan P3. Titer antibodi yang tinggi pada perlakuan P2 diduga karena dosis imunomodulator yang digunakan sesuai untuk membantu mengertak sistem kekebalan tubuh broiler jantan. Diferensial leukosit terdiri dari heterofil dan limfosit yang merupakan bagian dari sel darah putih yang juga berfungsi untuk pertahanan tubuh. Heterofil berfungsi sebagai pertahanan tubuh ayam terhadap pengaruh luar dan merupakan alat pendeteksi awal adanya infeksi (Mayes et al., 1997). 
Tingginya jumlah limfosit disebabkan adanya antigen virus ND yang masuk ke dalam tubuh sehingga limfosit meresponnya dengan memproduksi antibodi. Perlakuan P2 $(64,00)$ memiliki antibodi yang lebih tinggi dibandingkan pada perlakuan P1 (17,33). Hal ini sesuai dengan pernyataan Suardana (2017) bahwa Apabila dosis minimal suatu antigen telah dilampaui, maka semakin tinggi dosisnya, respons imun akan meningkat secara sebanding.

Berdasarkan uji lanjut BNT didapatkan hasil bahwa perlakuan $\mathrm{P} 3$, jika dibandingkan dengan P0, P2 dan P3 tidak berbedanyata. Dosis yang terlalu tinggi pada perlakuan P3 dengan dosis $144 \mathrm{mg} / \mathrm{kg} \mathrm{BB} /$ hari justru membuat titer antibodi menurun. Pada dosis tertentu (dosis maksimal) akan mengakibatkan penurunan respon imun atau bahkan dapat menghilangkan imun sama sekali dan keadaan ini disebut dengan toleransi imunologik. Yilmaz et al. (2011) menyatakan efek negatif dari tumbuhan herbal berkaitan dengan unsur racun, dosis tinggi dan kondisi alergi, tetapi apabila digunakan dengan dosis tepat tidak mengganggu kesehatan. Francis et al. (2002), menambahkan bahwa kandungan saponin dalam jintan hitam dengan jumlah normal berperan sebagai immunostimulator, sedangkan dalam jumlah yang melebihi batas normal saponin akan berperan sebagai immunosupresor (zat yang menekan/menurunkan sistem imun).

Nigella sativa termasuk obat herbal sebagai imunomodulator dengan khasiat sebagai antioksidan, anti inflamasi, anti mikroba, anti neoplasma dan dapat meningkatkan sekresi insulin (Salama, 2010). Hal ini mengindikasikan bahwa kandungan senyawa dari Nigella sativa memiliki efek potensiasi yang baik terhadap imunitas seluler yang diperantarai sel T. Efek imunostimulasi Nigella sativa diperkirakan dengan cara meningkatkan respon imunitas seluler, namun respon imunitas seluler tidak dapat diukur pada Laboratorium Virologi Balai Veteriner Lampung.

Biji jintan hitam memiliki kandungan fixed oils, essential oils, protein, alkaloid dan saponin, namun aktivitas biologi yang terlihat paling menonjol dari biji ini adalah thymoquinone. Thymoquinone diketahui merupakan sumber dari antioksidan (Ali dan Blunden, 2003). Thymoquinone memiliki efek sitoprotektif dari sitotoksisitas melalui mekanisme antioksidan (Mousavi et al., 2010).

Senyawa golongan kuinon hadir dalam minyak atsiri, Thymoquinone yang mampu berperan sebagai imunostimulan. Menurut hasil penelitian Fetriza (2013) kandungan zat aktif thymoquinone pada Nigella sativa berpengaruh terhadap luas korteks timus, luas folikel bursa fabrisius dan meningkatkan ukuran luas pulpa putih (folikel limfoid) pada broiler. Luas korteks timus digunakan untuk melihat aktivitas poliferasi limfosit, luas korteks timus akan mempengaruhi kepadatan sel yang dihitung sebagai parameter respon kekebalan tubuh dari organ limfoid timus. Luas folikel bursa fabrisius berpengaruh terhadap kepadatan sel limfosit, proliferasi limfosit merupakan penanda adanya fase aktivasi dari respon imun tubuh, proliferasi limfosit ini berupa peningkatan produksi limfoblast yang kemudian menjadi limfosit selain itu Kandungan Thymoquinone pada Nigella sativa menstimulasi sumsum tulang dan sel imun, produksi interferon, melindungi kerusakan sel oleh infeksi virus, menghancurkan sel tumor, dan meningkatkan jumlah antibodi yang diproduksi sel B, meningkatnya ukuran luas pulpa putih akan meningkatkan juga kepadatan sel sehingga pusat germinativum pada limpa akan meningkat dan melakukan perannya dalam respon humoral, yaitu dengan produksi antibodi dan menentukan kelanjutan sel B memori ke organ limfoid perifer.

Menurut Khoirunisa dan Sumiwi (2019) flavonoid memiliki efek untuk meningkatkan kesehatan dengan spektrum yang luas dan merupakan komponen yang sangat diperlukan dalam berbagai nutraceutical, farmasi, obat dan aplikasi kosmetik. Hal ini disebabkan karena flavonoid memiliki beragam aktivitas seperti antioksidan, antiinflamasi, antimutagenik dan sifat antikarsinogenik ditambah dengan kapasitasnya untuk memodulasi seluler kunci fungsi enzim. Zat aktif yang juga diduga memiliki peran sebagai imunostimulan adalah flavonoid. Flavonoid diduga mampu menginduksi peningkatan sekresi sitokin yang terlibat dalam proses aktivitas sel T. Flavonoid juga dapat dinyatakan sebagai komponen yang bersifat imunomodulator yang mampu meningkatkan sistem kekebalan tubuh.

Menurut Tenggara et al. (2014) flavonoid adalah suatu kelompok senyawa fenol yang banyak terdapat di alam. Aktivitas biologis senyawa flavonoid terhadap bakteri dilakukan dengan merusak dinding sel dari bakteri yang terdiri atas lipid dan asam amino. Dinding sel bakteri akan bereaksi dengan gugus alkohol pada senyawa flavonoid sehingga dinding sel akan rusak dan senyawa tersebut dapat masuk ke dalam inti sel bakteri, selanjutnya gugus alkohol ini akan kontak dengan DNA pada inti sel bakteri melalui perbedaan kepolaran antara lipid penyusun DNA dengan gugus alkohol pada senyawa flavonoid, sehingga bakteri tidak dapat berkembang dengan baik dan tidak. 
Faktor hormon diduga memberikan pengaruh terhadap pembentukan titer antibodi ND yang tidak protektif pada kelompok perlakuan karena setiap individu broiler jantan memiliki kadar hormon testosteron yang berbeda-beda. Hormon seks mengatur fungsi kekebalan tubuh bawaan dari monosit, sel dendritik, makrofag, sekresi interferon, dan produksi sitokin. Broiler jantan memiliki hormon testosteron yang dapat berdampak secara tidak langsung pada sel-sel kekebalan (Klein et al., 2014). Hormon kelamin akan ikut berperan dalam sistem kekebalannya jika ternak telah mencapai dewasa kelamin. Testosteron dan hormon seks lainnya memainkan peran dalam imunitas dan berdampak pada aktivitas sel B. Testosteron juga memiliki reseptor, namun justru menurunkan jumlah molekul sel B serta tidak memiliki pengaruh terhadap sel B seperti estrogen (Voigt et al., 2019). Rohyati (2002) menyatakan bahwa perkembangan bursa fabricius ayam jantan sangat terhambat oleh aktivitas testosteron. Bursa fabrisius merupakan organ limfoid yang hanya dimiliki oleh unggas dan berfungsi sebagai penghasil dan tempat pendewasaan limfosit serta berisi makrofag dan sel plasma. Menurut Fetriza (2013) bursa fabrisius berpengaruh terhadap kepadatan sel limfosit, proliferasi limfosit merupakan penanda adanya fase aktivasi dari respon imun tubuh, proliferasi limfosit ini berupa peningkatan produksi limfoblas yang kemudian menjadi limfosit yang menstimulasi sumsum tulang dan sel imun.

Vaksinasi merupakan cara yang paling umum diterapkan untuk mencegah penyakit yang disebabkan pleh virus. Ada dua strategi utama yang digunakan dalam pembuatan vaksin, yaitu live dan killed. Vaksin ND live dalam penelitian ini diberikan pada hari ke-6 (bersama dengan vaksin ND dan AI killed). Pada penelitian ini terdapat dugaan bahwa tingginya titer antibodi ND dibandingkan titer antibodi AI disebabkan adanya pemberian vaksin ND live. Vaksin killed/inaktif mengandung oil adjuvant sehingga proses pelepasan antigen menjadi lebih lambat. Oil adjuvant di samping berfungsi untuk memperlambat pelepasan antigen juga mampu meningkatkan daya imunogenik vaksin. Waktu relatif lama untuk memicu pembentukan antibodi maksimal, namun respons kekebalan yang terbentuk dapat bertahan lebih lama di dalam tubuh ayam dibandingkan dengan penggunaan vaksin livelaktif yang dapat memicu pembentukan antibodi maksimal dalam waktu yang singkat (Aiyer et al., 2013).

\section{SIMPULAN DAN SARAN}

\section{Simpulan}

Berdasarkan penelitian yang telah dilakukan dapat disimpulkan bahwa pemberian Jintan hitam (Nigella sativa) tidak berpengaruh nyata terhadap titer antibodi Avian Influenza, namun berpengaruh nyata terhadap titer antibodi Newcastle Disease pada broiler jantan dan pemberian Jintan hitam (Nigella sativa) sebanyak $72 \mathrm{mg} / \mathrm{kg}$ BB/hari merupakan dosis terbaik yang dapat meningkatkan titer antibodi Newcastle Disease pada broiler jantan.

\section{Saran}

Perlu adanya penelitian lanjutan dengan pemberian dosis terendah (72 $\mathrm{mg} / \mathrm{kg} \mathrm{BB} / \mathrm{hari}$ ) dengan pemeliharaan yang lebih lama dan pengambilan sampel darah dan pengecekan titer antibodi dilakukan pada saat pembentukan titer antobodi mencapai titik puncak serta pengambilan sampel darah setiap minggu untuk mengetahui rentang waktu pemberian Nigella sativa yang efektif dalam meningkatkan kesehatan broiler.

\section{DAFTAR PUSTAKA}

Aiyer, H. P., H. G. Ashok, G. P. Kumar, dan N. Shivakumar. 2013. An overview of immunologic adjuvants. $J$. Vaccines. 4(1): $2-4$.

Alfons, M.P.W. 2005. Pengaruh Berbagai Metode dan Dosis Terhadap Efikasi Vaksin Avian Influenza (AI) Inaktif. Skripsi. Fakultas Kedokteran Hewan. Institut Pertanian Bogor. Bogor.

Ali, B.H. dan G. Blunden. 2003. Pharmocological and toxicological properties of Nigella sativa. J. Phytotheraphy Research. 17(4): 299.

Allan, W.H., J.F. Lancaster, dan B. Toth. 1978. Newcastle Disease Vaccines, Their Production and Use. Food and Agriculture Organization of The United Nations. Rome.

Badan Pusat Statistik (BPS). 2020. Pendapatan Bruto Indonesia tahun 2015--2020. Badan Pusat Statistik Indonesia. Jakarta.

Baratawidjaja, K. G. 2009. Imunologi Dasar edisi ke-8. Balai Penerbit Fakultas Kedokteran Universitas Indonesia. Jakarta. 
Ekaningtias M., Wuryastuty H., Wasito. 2017. Pendekatan Diagnosis AvianInfluenza Virus dan Newcastle Disease Virus pada Kasus Lapangan AyamPetelur: Imunopatologis Streptavidin Biotin. $J$. Saint Veteriner. 35(1): 118--126

Fetriza, Z. 2013. Studi Histopatologi Pengaruh Ekstrak Minyak Jintan Hitam (Nigella Sativa) pada Organ Pertahanan Ayam Broiler. Skripsi. Institut Pertanian Bogor. Bogor.

Francis, G., K. Zohar, P.S.M. Harinder, and B. Klaus. 2002. The biological action of saponins in animal sistems. $J$. of Nutrition. 88: 587-605.

Hamal K.R., S.C. Burgess, I.Y. Pevzner, G.F. Erf. 2006. Maternal antibody transfer from dams to their egg yolks, egg whites, and chicks in meat lines of chickens. $J$. Poultry Science. 85:1364-1372.

Islam, S.K.N., P. Begum, T. Ahsan, S. Huque, and M. Ahsan. (2004). Immunosuppresive and cytotoxic properties of Nigella sativa. $J$. Phytotherapy Research. 18(5) : 395-398.

Kementrian Perdagangan. 2020. Analisis Outlook

Pangan 2015-2019. Pusat Kebijakan Perdagangan Dalam Negeri Badan Pengkajian Dan Pengembangan Kebijakan Perdagangan RI . Jakarta

Khoirunisa I. dan S.A. Sumiwi. 2019. Review Artikel: Peran Flavonoid Pada Berbagai Aktivitas Farmakologi. J. Farmaka 17(2):131-142.

Klein, S. L., I. Marriott, and E. N. Fish. 2014. Sex-based differences in immune function and responses to vaccination. $J$. of Trop Med and Hygiene. 109: 10-15.

Mayes P A, Murray R K, Granner D K, Rodwell V W. 1997. Biokimia Harper. $24^{\text {th }}$ Edition. Buku Kedokteran, Jakarta.
Mousavi SH, Z. Tayarani-Najaran, M. Asghari dan H.R. Sadeghnia. 2010. Protective effect of Nigella sativa extract and thymoquinone on serum/glucose deprivation-induced $\mathrm{PC} 12$ cells death. $J$. Cell. Mol. Neurobiol. 30(4): 591-598.

Prabowo, D. 2003. Maternal antibodi anak Ayam pelung yang induknya divaksin dengan vaksin ND kombinasi. J. Anim Prod. 5(1): 11--18.

Rohyati, N. 2002. Pengaruh Pemberian Probiotik B-Mix dan Infeksi Salmonella Enteritidis Terhadap Gambaran Mikroskopis Bursa Fabrisius pada Ayam Broiler. Skripsi. Fakultas Kedokteran Hewan, Institut Pertanian Bogor, Bogor.

Salama, R. H M. (2010).Clinical and therapeutic trials of Nigella sativa. TAF Prev Med Bull 9(5): 513-522.

Suardana I. B. K., 2017. Diktat Imunologi Dasar Sistem Imun. Universitas Udayana Denpasar. Bali.

Subowo. 2009. Immunobiologi Edisi 2. Sagung Seto. Jakarta

Tenggara F., Y. Rizka, dan K. Parisihni. 2014. Daya hambat ekstrak daun sirsak (Annona muricata) terhadap pertumbuhan bakteri mixed periodontopatogen. J.Kedokteran Gigi. 8 (2):103-226.

Voigt, E. A., I. G. Ovsyannikova, R. B. Kennedy, D. E. Grill, K. M. Goergen, D. J. Schaid, dan G. A. Poland. 2019. Sex differences in older adults immune responses to seasonal influenza vaccination. J. Frontiers of Immuno. 10:345-348.

Yılmaz S., S. Ergün, and N. Türk. 2011. Effects of cumin-supplemented diets on growth and disease (Streptococcus iniae) resistance of tilapia (Oreochromis mossambicus). J. Israeli Aquaculture. 64(768): $1-5$. 